\title{
MIĘDZY NIEBEM I ZIEMIĄ. RELACJE MIĘDZY CZLOWIEKIEM I JEGO PRZESTRZENIĄ JAKO ELEMENT PSYCHOLOGICZNYCH ROZGRYWEK BOLESŁAWA PRUSA Z JEGO WSPÓŁCZESNOŚCIĄ
}

\author{
MARCIN JAUKSZ1 \\ (Poznań)
}

Słowa kluczowe: przestrzeń, uwaga, pamięć, historia i teraźniejszość, nowoczesność

Keywords: space, attention, memory, history and present, modernity

\begin{abstract}
Abstrakt: Marcin Jauksz, MIĘDZY NIEBEM I ZIEMIĄ. RELACJE MIEDZY CZŁOWIEKIEM I JEGO PRZESTRZENIĄ JAKO ELEMENT PSYCHOLOGICZNYCH ROZGRYWEK BOLESŁAWA PRUSA Z JEGO WSPÓŁCZESNOŚCIĄ. „PORÓWNANIA” 11, 2012, Vol. XI, ss. 111-123, ISSN 1733-165X. Celem artykułu jest ukazanie kluczowego momentu w rozwoju Ignacego Rzeckiego, bohatera Lalki Bolesława Prusa. Autor, przypominając młodzieńcze lata bohatera, zwraca uwagę na jego udział w kampanii węgierskiej roku 1848 i znaczenie tego momentu, który ukazał młodemu subiektowi przepaść miedzy ideałem a rzeczywistością i dał Rzeckiemu umiejętność trafnego osądu późniejszych wydarzeń. Doświadczenie wojenne uczyniło z niego wprawnego uczestnika warszawskiego zgiełku późnych lat siedemdziesiątych i porte parole autora, gdyż obaj, będąc po swojemu artystami, starają się skierować uwagę innych ludzi na interesujące ich rzeczy i sprawy
\end{abstract}

Abstract: Marcin Jauksz, BETWEEN HEAVEN AND EARTH. RELATIONS BETWEEN A HUMAN BEING AND THEIR SPACE AS A PSYCHOLOGICAL ELEMENT OF BOLESŁAW PRUS' DEALINGS WITH CONTEMPORANEITY. "PORÓWNANIA" 11, 2012, Vol. XI, pp. 111-123, ISSN 1733-165X. The article aims at presenting a pivotal moment in shaping of the identity of Ignacy Rzecki, one of the main characters of Bolesław Prus's Lalka (The Doll). In reference to the character's background the author of the article proves that the participation in the Hungarian campaign of the year 1848 showed the difference between the ideal and the reality and gave Rzecki

\footnotetext{
${ }^{1}$ Correspondence Address: ma_walden@wp.pl
} 
an important ability of correctly judging subsequent events. His war experience makes him a skilful participant of Warsaw life in the late seventies and a porte parole to the author, both of whom being artists who aim at directing other people's attention onto issues and aspect of their interest.

\section{WSTĘP. NA POCZĄTKU... BYŁ NAPOLEON!}

Autobiografia Ignacego Rzeckiego zaczyna się, chronologicznie, jak większość opowieści o własnym życiu - od miejsca:

Mieszkaliśmy na Starym Mieście z ciotką, która urzędnikom prała i łatała bieliznę. Mieliśmy na czwartym piętrze dwa pokoiki, gdzie niewiele było dostatków, ale dużo radości, przynajmniej dla mnie. W naszej izdebce najokazalszym sprzętem był stół, na którym ojciec, powróciwszy z biura, kleił koperty; u ciotki zaś pierwsze miejsce zajmowała balia. Pamiętam, że w pogodne dnie puszczałem na ulicy latawce, a w razie słoty wydmuchiwałem bańki mydlane².

Dziecięce wspomnienia konstruuje Prus w równym stopniu konwencjonalnie, co sprytnie - wskazując już za sprawą dziecięcych zabaw na niektóre elementy charakteru przyszłego autora pamiętników, raczej projektującego swym pisarstwem wymarzoną wersję rzeczywistości niż pozostającego w ścisłym związku z opisywaną materią rzeczy. Zabawy młodego Rzeckiego mają jednak znaczenie również za sprawą tła, jakie się zza nich wyłania, społecznego i geopolitycznego kontekstu dorastania młodego Ignacego.

Ciotka piorąca bieliznę dla urzędników i ojciec pracujący w podległej rosyjskim władzom wojskowym instytucji, jaką była Komisja Spraw Wewnętrznych, który „po godzinach" opowiada sobie z kolegami, również urzędnikami podległymi aparatowi carskiemu, opowieści o Napoleonie i jego opatrznościowej roli w dziejach Europy to szczególne otoczenie, reprezentatywnie jednak oddające duchowe życie średnich warstw społeczeństwa w latach trzydziestych na ziemiach zaboru rosyjskiego.

Jak pisze Jerzy Jedlicki,

polska klasa umysłowa egzystować (...) miała w społeczeństwie obezwładnionym, skrępowanym, odgrodzonym od europejskiego postępu i pozbawionym własnych instytucji, a nawet prawa artykułowania trywialnych interesów. (...)

Paradoksalnie, we wszystkich zaborach najbardziej chłonnym prawodawcą stało się państwo, budzące zazwyczaj niechęć swoją obcością i represyjną polityką, ale zarazem gotowe pomieścić w swym rozbudowanym aparacie administracyjnym dużą liczbę miejscowych aspirantów. Nie tylko urzędników różnego szczebla: także prawników (zwanych ogólnie urzędnikami państwowymi), lekarzy (...), inżynierów (...). Posada

2 B. Prus, Lalka. Opr. J. Bachórz. Wrocław 1998. Dalej zaznaczam bezpośrednio za cytatem w nawiasie $\mathrm{z}$ podaniem numeru tomu i strony. 
rządowa dawała przy tym największe poczucie stabilności: łatwo było ją stracić za nieprawomyślność, ale dużo trudniej za niekompetencję ${ }^{3}$.

Młody Rzecki, wyrasta zatem nie tylko pośród niepodległościowych nadziei i wyznawczo snutej legendy wielkiego wodza. To oczywiście odciśnie na nim piętno, ale dużo istotniejszy jest czas przyszły wiecznie niedokonany, w którym Rzeckiemu przyjdzie żyć do kresu jego dni, czas oczekiwań pokładanych w rodzie cesarskim, którego powinnością jest wyzwolić Europę.

Biografia Rzeckiego, którego losy śledzić ma czytelnik Lalki Bolesława Prusa, ma zaprowadzić go na Węgry gdzie weźmie udział w walkach o niepodległość i zdaniem komentatorów ${ }^{4}$ - na stałe okopie się na pozycjach ideowych 1848 roku, w znacznej mierze tracąc kontakt z rzeczywistością. Wydaje się jednak, że marzycielstwo i nostalgiczne wycofanie Rzeckiego można odczytywać też pod nieco innym kątem i w oparciu o interakcje z warszawską rzeczywistością pokusić się o określenie kilku nowych zasad jego wyobcowania i rozczarowania.

Zgodnie z Prusowską koncepcją wzajemnego oświetlania się charakterów $\mathrm{w}$ dziele literackim, Rzecki istnieje $\mathrm{w}$ znacznej mierze po to, by unaocznić różnice miedzy Wokulskim i poprzednim pokoleniem. Kosztem tej interpretacyjnej potrzeby unieważnia się podobieństwa miedzy tymi bohaterami, a te są chwilami znaczne. Ich obecność i obcość na tle wielkomiejskich przestrzeni czyni z nich momentami bliźniaczych uczestników nowoczesnego zgiełku (nawet jeśli jest to dla Rzeckiego przede wszystkim - jedynie zgiełk prowincjonalnej z perspektywy europejskiej Warszawy). Rzecki jako casus w badaniach nad kryzysem pozytywistycznego programu u kresu lat osiemdziesiątych pozwala opisać, dzięki swoim doświadczeniom, fundamenty tego rozczarowania. W jego pamiętniku odbijają się echem doświadczenia pokolenia wychowanego $\mathrm{w}$ polistopadowej Warszawie i jednocześnie udokumentowana zostaje strategia budowania postaci - reprezentanta swoich czasów - przez Bolesława Prusa. Tego rodzaju poszukiwania dla czytelnika Hipolita Taine’a, a był nim Głowacki, miały ogromne znaczenie. Jaki pisze autor Historii literatury angielskiej:

Jeżeliśmy spostrzegli, zapamiętali w człowieku jedno, dwa, trzy, następnie mnóstwo uczuć, czy to wystarcza, abyśmy poznanie tego człowieka poczytywali za zupełne? Czy zbiór spostrzeżeń stanowi psychologię? Nie; w tym wypadku, jak we wszystkich innych, po zgromadzeniu faktów następować musi poszukiwanie przyczyn. Niezależnie od tego, czy fakty należą do dziedziny fizycznej czy duchowej, muszą istnieć przyczyny, które je wytworzyły. Ambicja, odwaga, prawdomówność posiadają swoje przyczyny tak samo, jak trawienie, ruch mięśniowy i ciepło zwierzęce 5 .

\footnotetext{
3 J. Jedlicki, Dzieje inteligencji polskiej do roku 1918. Błędne koło 1832-1864. Warszawa 2008, s. 51.

${ }^{4}$ Zob. J. Kulczycka-Saloni, Bolestaw Prus. Warszawa 1964, s. 130.

${ }^{5}$ H. Taine, Historya literatury angielskiej. Cz. I. Przeł. E. Orzeszkowa. Warszawa 1900, s. 12.
} 
Poszukiwanie źródeł polskiej duchowości jest zadaniem, którego wypełnienie rozpisuje Prus na setkach stron swych kronik, publicystyki i utworów beletrystycznych. Bohaterowie Prusa są dowodem w sprawie niepowodzenia cywilizacyjnego projektu pozytywizmu i określają dalsze perspektywy. Bo te wciąż są, roztaczają się wokól, mimo zwątpień i poczucia niedostatku.

Rzecki uosabia znakomicie schizofreniczny charakter dziedzictwa, jakie otrzymują obywatele Kongresówki przedstawieni w powieściach Prusa - z jednej strony kultywują nieuzasadnione sny o potędze, z drugiej kalają wszelkie realne (w obrębie programu samego Głowackiego) nadzieje własnymi słabościami i ograniczeniami perspektyw. Są one efektem rozwoju psychiki niezdolnej godzić marzenia z oporną rzeczywistością. Społeczne realia i wychowanie, które ci bohaterowie odebrali, czynią ich $\mathrm{w}$ znacznej mierze niegotowymi na zwyczajne w gruncie rzeczy sytuacje życiowe. Trzeba jednak zaznaczyć, że zwyczajność nie oznacza tu już prostoty, że powszednie sprawy dziewiętnastowiecznej egzystencji nie są kompatybilne z kodami, którymi operują bohaterowie Prusa. Kładąca się u podstaw dziewiętnastego stulecia rewolucja wytrąca człowieka tego czasu z jego poczucia komfortu i zadomowienia. A doświadczenie to będzie powracać, raz jeszcze dotykając każdego pokolenia i wymuszając odczucie niedopasowania i zagubienia. Nowoczesne społeczeństwo, pisze Marshall Berman

czuje, że przyszło mu żyć $\mathrm{w}$ rewolucyjnej epoce, pełnej gwałtownych przewrotów w każdym wymiarze życia osobistego, społecznego i politycznego. Równocześnie jednak dziewiętnastowieczne społeczeństwo nowoczesne pamięta, jak to jest żyć w świecie, który pod względem duchowym i materialnym nie ma z nowoczesnością nic wspólnego. Właśnie z owego wewnętrznego rozdarcia - z poczucia jednoczesnego zamieszkiwania dwóch światów - wypływają idee modernizacji i modernizmúb.

Metafizyczne lęki i potrzeby, jakie stają się ich udziałem mogłyby, sugeruje to Prus wyraźnie, stanowić furtkę do pełnej i samodzielnej egzystencji. Społeczna pamięć starego świata, którą u Prusa ucieleśnia arystokracja, kładzie się kłodą pod nogami tych, którzy nowemu światu gotowi są postawić warunki. Narracje, jakimi nakarmiła ich młodość, paraliżują jednak również tychże właśnie „bohaterów nowych czasów". Wrodzone talenty i Wokulskiego, i Rzeckiego sprawiają, że autor przedstawia ich $w$ sympatycznym świetle, jakby wierząc $w$ ich sprawy i współczując im z powodu niemocy, na którą był zmuszony ich skazać. Niemoc ta bowiem definiuje społeczeństwo, jakie ich wydało - zarówno dojrzewającą inteligencję, jak i zmierzającą do kresu swego posłannictwa narodowego szlachtę - niemoc ufundowaną na dystansie rozciągającym się między niebem i ziemią, ideałem i realnymi sprawami tego świata.

${ }^{6} \mathrm{M}$. Berman, "Wszystko, co stałe, rozptywa się w powietrzu”. Rzecz o doświadczeniu nowoczesności. Przeł. M. Szuster. Wstęp A. Bielik-Robson. Kraków 2006, s. 17. 


\section{CZĘŚĆ I: MEANDRY PAMIĘCI...}

To, kim są bohaterowie Lalki w momencie, gdy ich poznajemy, warunkuje przeszłość. Mechanizmy pamięci, które wykorzystuje Prus, są, można powiedzieć, formułą narzuconą przez konwencję literackiego zapisu, wspomnień snutych na prywatny lub publiczny użytek. Dialog, w jaki wchodzi na kartach swego pamiętnika Rzecki, nie należy do szczególnie spektakularnych, dotyczy spraw prywatnych, osobistych wspomnień ${ }^{7}$. Niemniej u Prusa to, co prywatne, w życiu bohaterów pozostaje $\mathrm{w}$ ścisłym związku $\mathrm{z}$ ich miejscem $\mathrm{w}$ społeczeństwie, zadaniem, jakie $\mathrm{z}$ kompozycyjnego rozdania przypadło im $\mathrm{w}$ udziale odegrać dla wyrażenia idei narodu. Wspomnienia $\mathrm{z}$ kampanii węgierskiej w przypadku Rzeckiego pozwalają dopełnić portret wspominającego z tęsknotą dawne dni pięćdziesięcioparoletniego mężczyzny, ujmują też fundament zarówno tożsamościowego jak i cywilizacyjnego projektu Prusa.

W pamiętnych frazach drugiej odsłony Pamiętnika starego subiekta czytamy:

Wspólna podróż trwała niespodziewanie długo, bo aż do października 1849 roku, pamiętasz Katz, niezapomniany przyjacielu? Pamiętasz te długie marsze $\mathrm{w}$ spiekocie, kiedy nieraz piliśmy wodę z kałuży; albo ten pochód przez bagno, w którym zamoczyliśmy ładunki; albo te noclegi w lasach i na polach, kiedy jeden drugiemu spychał głowę z tornistra i ukradkiem ściągał płaszcz, służący za wspólną kołdrę?... A pamiętasz tarte kartofle ze słoniną, które ugotowaliśmy we czterech w sekrecie przed całym oddziałem? Tylem razy jadał od tej pory kartofle, ale żadne nie smakowały mi tak jak wówczas. Jeszcze dziś czuję ich zapach, ciepło pary buchającej z garnka i widzę ciebie, Katz, jak dla nietracenia czasu mówiłeś pacierz, jadłeś kartofle i zapalałeś fajkę u ogniska (I, 249-250).

Wezwanie Katza to pamiętnikarski chwyt retoryczny, ale jednocześnie coś więcej. Prus w doświadczeniach Rzeckiego i jego przyjaciela zamyka doświadczenie pokolenia, które wyrywa się z marazmu miałkiej konspiracji $\mathrm{w}$ rodzinnym gronie i oporu polegającego na wieszaniu na ścianie portretów Napoleona. Kampania węgierska i europejska Wiosna Ludów to punkty orientacyjne dla tych wszystkich, którzy w drugiej połowie XIX wieku będą się definiować jako spadkobiercy romantycznych nadziei na niepodległość. „Niewczesne uniesienie”, o którym w swych Dziejach Polski pisał Fryderyk Skarbek ${ }^{8}$, a któremu ulega z całą pewnością Rzecki, to konieczność, jaka spada na wychowanych tak młodych ludzi $i$ jest to uniesienie pozytywne, zarażające czytelnika entuzjazmem uwiecznionym we wspomnieniach. $\mathrm{Z}$ drugiej strony antymilitarystyczny, przeciw Henrykowi

7 O wyraźnie osobistym charakterze tej refleksji pisał Józef Bachórz; J. Bachórz, Najważniejszy dzień w życiu Ignacego Rzeckiego, w: Spotkania z "Lalkq". Mendel studiów i szkiców nad powieścia Bolestawa Prusa. Gdańsk 2010, s. 157.

8 F. Skarbek, Dzieje Polski, cz. III, Królestwo polskie po rewolucji listopadowej. Poznań 1877, s. 142. 
Sienkiewiczowi jakby tworzony ${ }^{9}$, opis ",jeneralnej bitwy", jej weryzm, pozwala określić szereg psychologicznych konsekwencji, jakie dla Rzeckiego niesie ze sobą to doświadczenie.

Sprowokowany do działania, jak pewna część jego rówieśników, którzy „z Galicji, Królestwa i z guberni ukraińskich przekradli się na Węgry", to wyraz przemożnej chęci działania „obudzonej po latach bierności”10. Udział w czynie zbrojnym, wyjście poza znajome ściany domowego rozpamiętywania, to ważny element $\mathrm{w}$ charakterystyce bohatera, którego ostatecznie zdefiniuje przecież odcięcie, niedopasowanie... Zwycięska bitwa, w której walczy u boku Katza, to moment szeregu przewartościowań, jakie dokonują się w duszy młodego subiekta. Rzutuje na wszystko, co i jak wtedy spostrzega. Perspektywa Rzeckiego staje się istotną lekcją uwagi, która, jak udowadnia Jonathan Crary, należy do fundamentalnych przesłanek dziewiętnastowiecznej wiedzy

Większość analizowanych czynników - czas reakcji, wrażliwość zmysłowa i percepcyjna, chronometria umysłu, odruchy i reakcje warunkowe - zakładała, że to uważność podmiotu jest terenem obserwacji, klasyfikacji i pomiarów, a zatem ośrodkiem wokół którego gromadziła się wiedza z różnych dziedzin ${ }^{11}$.

Rzecki opowiada bitwę nie jak historyk, ale jak cywil, który znalazł się w zamęcie bitewnym. Nie umie nazywać wszystkiego, co widzi dookoła. A widzi i tak wycinki:

W plutonach, które szły przed nami o jakieś sto kroków na lewo, zrobiło się zamieszanie; gdy zaś kolumna posunęła się dalej, zobaczyliśmy dwu ludzi: jeden leżał twarzą do ziemi, wyciągnięty jak struna, drugi siedział trzymając się rękoma za brzuch. Poczułem zapach prochowego dymu; Katz przemówił coś do mnie, alem go nie słyszał; natomiast zaszumiało mi w prawym uchu, jakby tam wpadła kropla wody.

Podoficer poszedł $\mathrm{w}$ prawo, my za nim. Kolumna nasza rozwinęła się we dwie długie linie. Na paręset kroków przed nami zakłębił się dym. Coś trąbiono, alem nie zrozumiał sygnału; natomiast słyszałem ostre poświsty nad głową i koło lewego ucha. O kilka kroków przede mną coś uderzyło w ziemię zasypując mi piaskiem twarz i piersi. Mój sąsiad strzelił; dwaj stojący za mną prawie na moich ramionach oparli karabiny i wypalili jeden po drugim. Ogłuszony do reszty, wypaliłem i ja... Nabiłem i znowu strzeliłem. Przed front spadł czyjś kask i karabin, ale otoczyły nas takie kłęby dymu, żem nic dalszego nie mógł dojrzeć. Widziałem tylko, że Katz, który ciągle strzelał, wygląda jak obłąkany i ma pianę w katach ust. Szum w uszach spotęgował mi się tak, żem w końcu nic nie słyszał, ani huku karabinów, ani armat (I, 259).

${ }^{9}$ Zob. J. Bachórz, op. cit., s. 153-154, 158.

${ }^{10} \mathrm{~J}$. Jedlicki, op. cit., s. 111.

${ }_{11}$ J. Crary, Zawieszenia percepcji. Uwaga, spektakl i kultura nowoczesna. Przeł. Ł. Zaremba i I. Kurz. Red. I. Kurz. Warszawa 2009, s. 41. 
Subiektywny ogląd bitwy Rzeckiego pozwala zaakcentować Prusowi znaczenie chaosu w żywiole wojennej praktyki, trudności, jakie napotyka człowiek wplątany w sytuację, która tak bardzo go przeraża. Rzecki jest "tylko" zagubiony, ale Katz „wygląda jak obłąkany i ma pianę w kątach ust” (I, 259) „krzyczy nieludzkim głosem" (I, 263) i ostatecznie rzuca się na Rzeckiego, który próbuje go wybić $\mathrm{z}$ amoku. Szaleństwo wojennego czasu zaprowadzi Katza ku samobójczej śmierci. Dla Rzeckiego wzmocni to tylko surowość doświadczenia, które tak dalece odbiega od wojskowych legend mieszczańskiego domostwa, snutych przy bańkach z mydlin ciotki piorącej urzędnicze ubrania. Odbiega też od chaosu Sienkiewiczowskich batalii, gdzie jeśli Zagłoba traci orientację $\mathrm{w}$ bitewnym zgiełku, to tylko po to, by zdobyć chorągiew i ozdobić pozytywistyczną chanson de geste lekką $\mathrm{w}$ tonie anegdotą. Zagubienie Rzeckiego jest już świadectwem autorskiego poszukiwania odpowiedzi na to, co nowoczesna wojna robi z człowiekiem, w jaki sposób wytrąca go z poczucia uporządkowanego i jasno określonego świata. Jest doświadczeniem nie mniej przełomowym od tego, którego staje się udziałem Stendhalowskiego Fabrycego, bohatera Pustelni parmeńskiej, podczas wyprawy pod Waterloo:

\begin{abstract}
Wsparty o wierzbę, zaczął płakać gorącymi łzami. Wyzbywał się kolejno marzeń o rycerskiej i szczytnej przyjaźni, jaka łączy bohaterów Jerozolimy wyzwolonej. Niczym byłoby mu patrzeć na zbliżającą się śmierć $w$ otoczeniu dusz braterskich i tkliwych, szlachetnych przyjaciól, którzy ściskają ci dłoń w chwili ostatniego tchnienia! Ale jak tu zachować święty zapał w pobliżu podłych łajdaków! (...)

Wojna nie była tedy owym szlachetnym i wspólnym porywem dusz rozkochanych w sławie, jak to sobie wyobrażał z proklamacyj Napoleona! Usiadł lub raczej osunął się w trawę. Pobladł mocno ${ }^{12}$.
\end{abstract}

Część powyższego fragmentu wykorzystał w Głównych prądach literatury XIX stulecia Georg Brandes, co mogło wskazać Prusowi romantyczne źródła wielkich rozczarowań stulecia, stanowiąc też, co istotne, literacką ilustrację jego własnych przeżyć. W listopadzie roku 1865 Prus pisał do Mścisława Godlewskiego:

W tej przeszłości, w której mnie poznałeś - już nie ma mnie. Ja, dawny ja, pochowany jestem razem z nadziejami moimi pod Białką, skąd drugi ja wyrósł: dwumiesięczne szaleństwo, zwątpienie w tego rodzaju zabawy i kalectwo, przy którym potrzeba było małego swędu w nocy i małej pół godziny więcej, a Twój listo odjechałby retro.

Krótko zakończę: mam rozklekotaną głowę, częste mdłości, ataki krwi do mózgu itp. - to mi dała przeszłość ${ }^{13}$.

\footnotetext{
12 Stendhal, Pustelnia parmeńska. Przeł. T. Żeleński (Boy). Warszawa 1985, s. 46-47.

${ }^{13}$ B. Prus, Listy. Oprac. K. Tokarzówna. Warszawa 1959, s. 24.
} 
Fundamentalna dla pisarstwa Beyle'a diagnoza, która głosi „prawdą jest tylko to, co odczuwamy"14, odnajduje w pisarstwie Prusa fenomenalne rozwinięcie. Głowacki reprezentuje odmienną wrażliwość i odmienne cele stawia przed literaturą, ale tematy, które podejmuje wiele wspólnego mają z refleksjami przepisanymi w zdarzenia Stendhalowskiej fikcji. Wojenny epizod Rzeckiego nieprzypadkowo pozwala Prus opowiedzieć subiektowi po finałowych rozważaniach Wokulskiego w rozdziale dziewiątym. Tam bowiem główny bohater wspomina własne dzieciństwo i pogardę dla dziecinnych marzeń:

Jakże mu wtedy, wygłodzonemu, smakował bułka i serdelek! Jak wyobrażał sobie siadłszy na konia karuzeli, że jest wielkim wojownikiem! Jak szalonego doznawał upojenia, wylatując do góry na huśtawce! (I, 241)

Teraźniejszość - w porównaniu - wypada w oczach Wokulskiego bardzo źle. Wielkomiejski żywioł, który karmi medytacje i inspiruje widzenia bohatera, to inny od bitewnego świat, ale poczucie wytrącenia z równowagi, które przynosi, jest dość podobne. Ostatecznie jednak to główny bohater Lalki odkrywa „oszustwo" młodzieńczych frazesów i ciężar brzemienia (tak jak i u Prusa) wynikającego z wojskowego etapu biografii. Rzecki nigdy nie odrzuci tego doświadczenia ono wszelako da mu rangę autorytetu w sprawach wszelakich. I w tym przypadku ranga ta niewątpliwie mu przysługuje. To, że miesza on narracje o wojnie i o Stachu, pokazuje nie tylko dygresyjny tryb myślenia człowieka piszącego dziennik; te przesunięcia uwagi ilustrują, w jaki sposób wojenne doświadczenie tułaczki, wykorzenienia i zagubienia znakomicie oświetlają kondycję nowoczesnego podmiotu. Mówiąc o finale lat czterdziestych bowiem, Rzecki jednocześnie mówi o uniwersalnych doświadczeniach człowieka wieku dziewiętnastego.

To, jak wyglądała wojna, widok Katza z dziurą po kuli w skroni, wszystko to stanowi ważki komentarz do późniejszych bolączek Wokulskiego i całej psychologicznej panoramy zawartej w Lalce. Rzecki, nie zdając sobie z tego sprawy, komentuje świat, który odtrąca i szybko zapomina o chwilowych triumfatorach, dowodząc im, ze realność doświadczeń przynosi rozczarowania nieuwzględnione w młodzieńczych nadziejach - pryskających niby bańki mydlane. Pytanie babki, po co jeździł na Węgry, stanowi dla Rzeckiego adekwatny komentarz również do

14 G. Blin, Stendhal i problemy powieści. Przeł. Z. Jarymko-Pytowska. Warszawa 1972, s. 126. G. Brandes stwierdza, że Beyle „w kolegach swoich nie znalazł wesołych, miłych i szlachetnych towarzyszy, jakimi sobie ich wyobrażał, ale tylko zgraję samolubnych nicponiów” i cytuje wypowiedź Stendhala dotyczącą fundamentalnego znaczenia tego rozczarowania: „Ja także nie miałem szczęścia do towarzyszy, teraz widzę, że w charakterze moim naonczas okazywałem bardzo śmieszną mieszaninę dumy i pędu do zabawy. Wobec szorstkiego samolubstwa innych chłopców objawiałem iście hiszpańskie, szlacheckie pojęcia honoru i na wpół wpadałem w rozpacz, gdy ci bawili się ze sobą, a ze mną nawet gadać nie chcieli"; J. Brandes, Gtówne prady literatury XIX stulecia. Szkota romantyczna we Francji. Warszawa 1885, s. 204. 
bułgarskiej eskapady Wokulskiego. Trud doświadczenia nie spłaca długów młodzieńczej egzaltacji, takiego czy innego (patriotycznego, miłosnego...) porywu serca. Rzecki podskórnie czuje, że jego doświadczenie może wyjaśnić to, przez co przechodzi (i ku czemu zmierza) Wokulski:

Kochany Stasiu, tyś sprytny, alem i ja nie w ciemię bity: wiem więcej, aniżeli przypuszczasz, i to mi tylko bolesne, że nie masz do mnie zaufania. Bo rada przyjaciela i starego żołnierza mogłaby cię uchronić od niejednego głupstwa, jeżeli nie od plamy... (I, 289)

Pan Ignacy, wróciwszy na stare śmieci, odnajdzie równowagę po tym, jak odgrodzi się od świata. Przetrwawszy rozczarowania tułaczki, oparłszy się pokusie samobójstwa - dzięki legendom ojca, którym na odsiecz przybędą wieści o Ludwiku Napoleonie i jego ucieczce -schowa się w sklepie, gdzie pozostanie już do śmierci. Ostatecznie zatem biografię Rzeckiego można odczytać jako wypełnienie diagnozy Waleriana Kalinki, który z szeregu konserwatystów galicyjskich pisał w 1853 roku: „droga po której nas dotąd wiedziono, droga rewolucyjna, od szałów i niecierpliwości prowadzi do niemocy i znużenia"15. Można, ale nie bez szczególnego przypisu.

\section{CZĘŚĆ II: REŻYSER I JEGO ZABAWKI}

Fakt, że Rzecki pewnie i swobodnie czuje się jedynie we własnym mieszkaniu i w sklepie udawadniał w swym studium o neurotycznych bohaterach Prusa Jan Tomkowski ${ }^{16}$. Poczucie bezpieczeństwa zapewniają subiektowi jedynie przestrzenie znajome, oswojone... Autor Mojego pozytywizmu wskazuje jako symptomatyczną scenę wizyty w teatrze, gdzie wysłany przez Stacha Rzecki czuje się zagubiony, niepewny i - rzeczywiście - za sprawą staromodnego ubrania wyróżnia się w tłumie. To i inne doświadczenia (choćby spacerów, których zaniechuje po tym, jak dostrzega, że ludzie zwracają na niego uwagę przez jego niemodny strój) zamykają bohatera, jak pokazuje J. Tomkowski, w czterech ścianach jego pokoju.

Niemniej jednak, stary subiekt odciska swoje piętno na przestrzeni, która go odrzuca i wchodzi z nią w kontakt na unikalnych zasadach. Scena teatralna ma tym samym znaczenie nie tylko jako dowód w sprawie jego charakteru, ale też jako jedna z chwil, w których widać ewidentnie, w jaki sposób neurotyczni bohaterowie Prusa (zanalizowani przez Tomkowskiego) są w stanie okiełznać nieprzychylną im przestrzeń.

Ogromne znaczenie terapeutyczne może mieć, jak chce badacz, pisanie pamiętnika, praktyka rozmów z samym sobą o ważnych sprawach. Ale nie mniej

\footnotetext{
${ }^{15}$ W. Kalinka, Galicya i Kraków pod panowaniem austriackim. Kraków 1898, s. 14.

16 J. Tomkowski, Mój pozytywizm. Warszawa 1993, s. 154.
} 
istotna jest symboliczna scena zabawy wszystkimi mechanicznymi zabawkami nakręconymi jednocześnie podczas niedzielnego święta, które dla Rzeckiego streszcza się w układaniu planu wystaw sklepowych na cały tydzień. Rzecki zagospodarowujący sklepowe okno jest równie istotny jak ten, który chwilę później chichotał będzie nad jedną z nakręcanych figur - niedźwiedziem wdrapującym się na słup. W niedzielę wieczorem przez chwilę to Rzecki jest bowiem reżyserem dla świata, który na co dzień go odrzuca. Rzecki układający wystawę na moment wychodzi poza swoją zamkniętą (pozornie) przestrzeń.

$\mathrm{W}$ jego pojęciu okna nie tylko streszczały zasoby sklepu, ale jeszcze powinny były zwracać uwagę przechodniów bądź najmodniejszym towarem, bądź pięknym ułożeniem, bądź figlem. Prawe oko, przeznaczone dla galanterii zbytkownych, mieściło zwykle jakiś brąz, porcelanową zastawę buduarowego stolika, dokoła których ustawiały się albumy, lichtarze, portmonety, wachlarze, w towarzystwie lasek, parasoli, niezliczonej ilości drobnych a eleganckich przedmiotów. W lewym znowu oknie, napełnionym okazami krawatów, rękawiczek, kaloszy i perfum, miejsce środkowe zajmowały zabawki, najczęściej poruszające się. (I, 36)

Z odrzuconego przez rytm nowoczesnego miasta neurotyka Rzecki w chwilach aranżacji wystawy okiennej staje się demiurgiem specyficznej sytuacji, bez dwóch zdań - wielkomiejskiej, wykreowanej na własnych zasadach. Jej mechanizm rozumie bowiem tak dobrze, jak naturę i metaforyczny sens ukryty w nakręcanych mechanicznych zabawkach.

Wystawa okienna urządzana przez starego subiekta jest zaproszeniem, ale i atakiem na uwage przechodnia, wydarzeniem, które ma wytrącić go z rutyny pośpiechu i zwabić do sklepu. Neuroza Rzeckiego w równym stopniu odsuwa go od świata, co każde ten jego reprezentantów zwabiać w swoje progi, by we własnym świecie rozegrać inną już partię na dobrze sobie znanych zasadach. A wywabienie przechodnia z jego rutyny może być uznane za sukces. Jak pokazywał Georg Simmel w swym studium o Mentalności mieszkańców wielkich miast,

psychologicznym tłem indywidualności wielkomiejskiej jest natężenie podniet n e r w o w y ch, wynikające z nieustannych zmian zewnętrznych i doznań wewnętrznych. Człowiek jest istotą uwrażliwioną na różnice, jego świadomość rejestruje różnice miedzy doznaniem aktualnym i doznaniem poprzednim. Powtarzające się doznania, mało się od siebie różniące, na pamięć znany rytm ich kolejnych nawrotów mniej zużywa - jeżeli można tak powiedzieć - świadomość niż natłok szybko zmieniających się obrazów, nieciągłość i zróżnicowanie doznań jednocześnie bombardujących świadomość, nieoczekiwane wrażenia. Takie właśnie warunki psychologiczne stwarza wielkie miasto, takich bowiem wrażeń dostarcza nam każde przejście przez ulicę, obserwacja tempa i różnorodności życia gospodarczego, zawodowego, społecznego ${ }^{17}$.

${ }^{17}$ G. Simmel, Most i drzwi. Wybór esejów. Przeł. M. Łukasiewicz. Warszawa 2006, s. 115. 
Doświadczony w chaosie bitewnej walki Rzecki, którego rytm dnia nie mógłby być bardziej zrutynizowany, jest tym, który kradnie pośpiesznemu i dynamicznemu mieszczuchowi chwilę uwagi. Wystawa sklepu Wokulskiego może kogoś zatrzymać na chwilę... albo na dłużej. Okazuje się, że rozpoznający trywialność ludzkich zaangażowań Rzecki, trochę w tonie Szekspirowskiego żartu, ale ze skrytą za pazuchą filozofią Eklezjasty, błahostki i głupstwa życiowe umie wygrać na swoją korzyść. Handel to ta sztuka, w której zaprawdę jest artystą, tym przenikliwszym i sprytniejszym, im bardziej odsuniętym od świata, który go nie rozumie i uznaje, że ewidentnie nie służy mu starokawalerstwo ${ }^{18}$. Uważany za „bzika” Rzecki także podczas swej wyprawy do teatru, zawstydzony, ślubuje sobie nie odwracać oka od dziurki w kurtynie. To ciekawe, że Prus skupia jego uwagę akurat na tym elemencie, jakby nakazując artyście witryn sklepowych rozpoznać miejsce, z którego patrzy na niego nie szydzący tłum, ale kolega-artysta, ten, którego fach polega na również na angażowaniu uwagi widza, tyle, że w teatrze.

Co więcej, uznany za szlachcica z Wołynia Rzecki, zdoła sprytnie (nieważne że zdesperowany) zamienić się na gorsze miejsce z panem Pifke, by ukryć się przed tymi, którzy patrzą z ciekawością, zdumieniem, niechęcią... Stamtąd też, już gdy rozpocznie się spektakl, szybko i sprawnie zauważy inne elementy "nieoficjalnej” reżyserii:

Kiedy piękne oblicze panny Izabeli wyrażało najwyższy zachwyt, wtedy Wokulski pocierał sobie ręką wierzch głowy. A wówczas, jakby na komendę, z galerii i z paradyzu odzywały się gwałtowne oklaski i wrzaskliwe okrzyki: „Brawo, brawo Rossi!...” Zdawało się nawet panu Ignacemu, że gdzieś w tym chórze odróżnia zmęczony głos inkasenta Obermana, który pierwszy zaczynał wrzeszczeć, a ostatni milknął.

„Do diabła - pomyślał - czyżby Wokulski dyrygował klakierami?" (Prus 1998, t. I, s. 533)

Rzecki szybko przed samym sobą wycofuje się z tych podejrzeń, jednak fakt, że Prus w ogóle pozwala mu je dostrzec, zdradza autorski koncept definiujący niedopasowanych idealistów. Rzecki jest jak Wokulski zapatrzony w pannę Łęcką. Omamiony, bezwolny, upokorzony (niby stary subiekt w pierwszym rzędzie krzeseł po zjawieniu się $\mathrm{w}$ teatrze) pozostaje aktywnym uczestnikiem i wytrawnym graczem w obrębie swoich kompetencji i własnych możliwości. Wokulski, który daje pannie Izabeli to, czego ona potrzebuje, jest reżyserem teatralnej sytuacji, w której Łęcka jest co najwyżej muzą, zaś wszyscy inni - Rossi, inni aktorzy i cała

18 Co ciekawe - Prus sympatyzujący ewidentnie z tym wymiarem bytowania swego bohatera ukazuje różnicę, między zaangażowaniem, jakie cechuje pozytywistyczny uzus sztuki - w tym przypadku głównie dekoratorskiej i użytkowej, ale w sensie ogólnym można rzecz przecież rozwinąć o inne jej gałęzie - a przemocą sprzedawcy, który w oczach Waltera Benjamina deprecjonował będzie sztukę przez zagospodarowanie nią sklepowych wystaw. Zob. S. Buck-Morrs, The Dialectics of Seeing: Walter Benjamin and the Arcades Project. Cambridge: 1991, s. 136. 
publiczność to pionki w jego osobistym spektaklu na cześć ukochanej. Byłby pionkiem i Rzecki, ale trochę z przypadku, trochę dzięki podskórnej przenikliwości, odstępuje swoją rolę Pifkemu.

Naiwność Rzeckiego, który swoją narracją będzie się coraz bardziej odgraniczał od rzeczywistości i „obiektywnego" stanu rzeczy, nie przeszkadza mu dostrzegać spraw istotnych. Nie zawsze trafne interpretacje zjawisk dokonywane przez Rzeckiego nie zmieniają faktu, ze zwraca on uwagę na rzeczy istotne i - jeśli nawet tylko w koszmarach pijanego - zawsze potrafi rozpoznać ich rangę. Rzeckiego nazwać można mistrzem uwagi, dzięki zdystansowaniu względem współczesności zdolnego wykorzystywać pewne jej mechanizmy. Ten idealista buduje mikroświat, w którym jego nadzieje, ukryte przed ciekawskim tłumem, wciąż mogą żyć niezagrożone przez rzeczywistość, stając się tym samym graczem o ileż wytrawniejszym od Wokulskiego.

\section{ZAKOŃCZENIE ALBO KUKIEŁKI BOLESŁAWA PRUSA}

Gry z uwagą Prusowskich bohaterów osadzonych w warszawskim żywiole dynamicznej, choć podszytej melancholią codzienności, bardzo wyraźnie wpisują się $\mathrm{w}$ rozwojowe drogi polskiego pozytywizmu jako nurtu żywo reagującego na procesy modernizacyjne i padającego ich (mimowolną) ofiarą. Traumy niedalekiej przeszłości z jednej i sceptycyzm wyrosły na marginesie rozwijającego się coraz dynamiczniej społeczeństwa $z$ drugiej strony są filarami twórczych założeń Prusa u kresu lat osiemdziesiątych. To, co je łączy, to niegasnąca - podobna do tej Rzeckiego - nadzieja budowania więzi i ocalenia idei, które naprawdę mają znaczenie i wywiedziona z kształtującej się koncepcji podmiotu wola podporządkowania sobie (choćby na chwilę) świata tak często miałkiego i niezainteresowanego diagnozami toczących go chorób.

Swoje konfrontacje z współczesnością rozpoczyna Głowacki jeszcze w wieku młodzieńczym. Wtedy też jego spotkanie z chaosem cechującym militarne działania wyprowadza go na pozycje słusznej dydaktyki, tej, którą po latach, nie zostawszy, jak marzył, naukowcem będzie mógł wykorzystać jako kronikarz i jako beletrysta. Intryguje uwaga poczyniona w cytowanym już liście do Godlewskiego z 1865 roku, odnosząca się do niewyjaśnionego nieporozumienia między przyjaciółmi.

$\mathrm{Na}$ koniec bez ogródki powiedziałeś mi, że nigdy nie będziesz moim narzędziem; przyznam się, że to jest zabawne i rzuca ślad niejaki na Twoje stosunki w Szkole Głównej. Ty moim narzędziem? A wiesz o tym, że ja, jeżelim nawet robił kogo narzędziem, to tylko po to, aby go natchnąć samodzielnością, że kilku nawet, którzy kiedyś na mnie może rzucą się - dostali siłę tylko ode mnie ${ }^{19}$.

${ }^{19}$ B. Prus, Listy, op. cit., s. 24. 
Ne ma możliwości, zaznacza Krystyna Tokarzówna, rozsądzić o powodach, dla których Godlewski czuł się narzędziem Głowackiego ${ }^{20}$. Niemniej samo poczucie przyjaciela przyszłego autora Lalki pokazuje, jak wcześnie kształtowały się zręby artystycznych koncepcji Prusa.

Ostatecznie okazać ma się wszak, że zadaniem ogólnym tworzenia dzieła jest, jak stwierdza Prus w notatkach o kompozycji przeszło dwie dekady później, wprowadzić czytelnika za pomocą bohatera „w jakieś: nowe, piękne i pouczające sytuacje"21. Co więcej, pytania, jakie stawia sobie Prus, to te o szansę reżyserii recepcji:

1) Jaki wpływ mam zamiar wywrzeć na w o lę czytelnika?

2) Jak przedstawić rzecz, aby ją dokładnie z r o z u m i a ł?

3) Jak przedstawić szczegóły, aby je w i d z i a 1, o d c z u w a ł i c z u 1 ?22

Teatr świata Bolesława Prusa rządzi się prawami, które rozpoznają sami jego bohaterowie - wyrzuceni na margines pędzącej cywilizacji neurotycy. Wyobcowanie ich (tak Wokulskiego, jak i Rzeckiego) podszyte jest przemożną potrzebą przywrócenia zależności, odbudowania kontaktu. W zasadach powieściopisarstwa Prusa (które pisarz ujmuje w prawidła podczas pisania Lalki) wyraz odnajdują dekoratorskie zamiłowania Rzeckiego urządzającego sklepową wystawę. Prusowskie zaproszenie do wykreowanego przez siebie świata - można uznać po lekturze młodzieńczego listu - ma sokratejskie korzenie, niemniej jest wykalkulowanym na chłodno, z matematyczną ( $\mathrm{w}$ założeniu) dokładnością projektem uwiedzenia $\mathrm{w}$ sytuacje, w których czytelnik poczuje się zaskoczony, oszołomiony - w efekcie zaś (pozytywnie) odmieniony.

W Wokulskim, który po powrocie z zesłania, jak pisze Rzecki w swym pamiętniku, odnajduje się bezradny, odtrącony przez wszystkich „uczepiony między niebem a ziemią" (II, 47), ucieleśniona zostaje autorska perspektywa spoza świata. Bóg oddzielający sklepienie niebieskie od ziemi tworzy przestrzeń "pomiędzy", która okaże się domem wszystkich duchów oderwanych, niepewnych. Polityczne, społeczne, kulturowe lekcje, jakie środkowoeuropejski układ sił daje w połowie dziewiętnastego stulecia dwóm pokoleniom polskich entuzjastów, odbijają się w Lalce głośnym echem; równocześnie jednak powieść ta jest opisem procesów, które pozwoliły tym społecznym doświadczeniom ukształtować konkretne strategie artystyczne, poetykę powieści, która stawia opór sceptycyzmowi i w regułach kompozycji ukrywa mechanizmy pozwalające uwolnić się od bagażu nostalgii a także wykorzystać doświadczenia, jakie przynosi nowoczesność, w uczciwej grze fabularnych nauczek i zachwytów.

\footnotetext{
20 Zob. ibidem, s. 26.

${ }^{21}$ B. Prus, Literackie notatki o kompozycji. Wybór i oprac. A. Martuszewska. Gdańsk 2008, s. 164.

22 Ibidem, s. 88.
} 


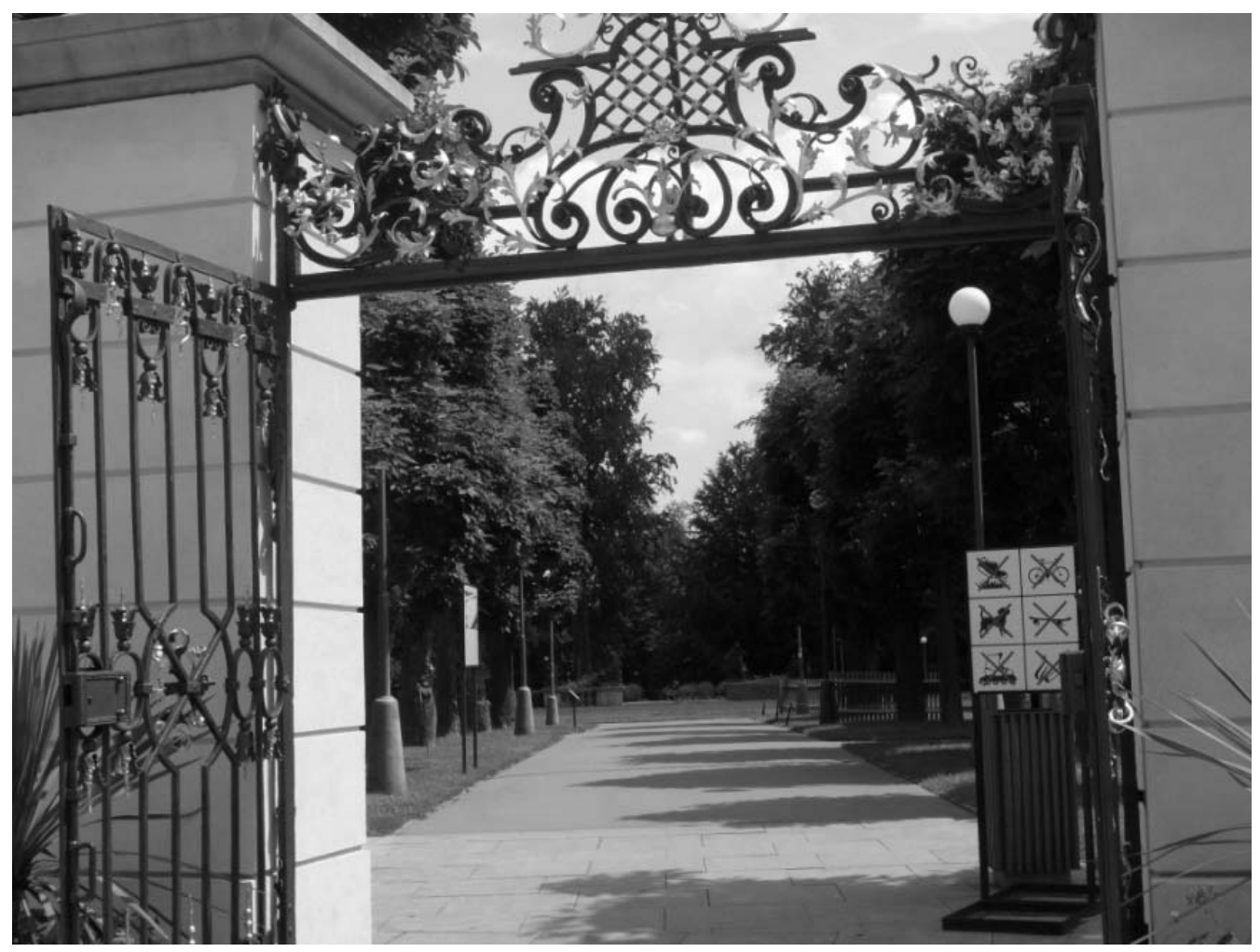

